\title{
PHOTOTHERAPEUTIC HARDWARE COMPLEX FOR REHABILITATION, PREVENTION AND TREATMENT OF DISEASES OF THE HUMAN CENTRAL NERVOUS SYSTEM
}

\author{
A.M. Korobov \\ Cand. Sci. (Phys.-Math.), Head of the laboratory \\ Science and Research Laboratory of Quantum Biology \\ and Quantum Medicine \\ V.N. Karazin Kharkiv National University \\ 6 Svobody Sq., Kharkiv, 61022, Ukraine \\ tel: +38 (057) 707-51-91 \\ e-mail: amkorobov@karazin.ua \\ ORCID 0000-0001-8237-7159
}

\author{
V.A. Korobov \\ Researcher \\ Research and Prodaction Medical and Biological \\ Corporation "Laser and Health" \\ 1 Zhukovskogo Av., off. 99, Kharkiv, 61085, Ukraine \\ tel.: +38 (050) 031-98-62 \\ e-mail: korobov_vsevolod@bigmir.net \\ ORCID 0000-0002-2848-0929
}

\author{
M.F. Posokhov \\ Cand. Sci. (Med.), Docent, Head of the department \\ Department of Functional Neurosurgery with a group of \\ pathomorphology \\ "Institute of Neurology, Psychiatry and Narcology of the \\ NAMS of Ukraine" State Institution \\ 46 Akademika Pavlova St., Kharkiv, 61068, Ukraine \\ tel: +38 (050) 677-77-53 \\ e-mail:posohov@bk.ru \\ ORCID 0000-0003-3361-5522

O.V. Kozyr
Junior Researcher
Science and Research Laboratory of Quantum Biology
and Quantum Medicine
V.N. Karazin Kharkiv National University
6 Svobody Sq., Kharkiv, 61022, Ukraine
tel: +38(057)707-51-91
e-mail: kbkm@karazin.ua
ORCID0000-0001-9854-9170

Introduction. The significant prevalence of vascular diseases of the brain, the complexity of dysfunction, put the problems of their treatment, rehabilitation and prevention into the focus of attention of modern neurology. A stroke occurs in the United States every 45 seconds. Approximately 750,000 people a year suffer from a stroke in the United States. According to statistics from the Ministry of Health of Ukraine, more than 110,000 primary strokes are recorded annually in the country. No less serious disease of the human central nervous system is Alzheimer's disease. Each year, more than 500,000 Americans die from this disease, making it the third leading cause of death in the United States. Traffic accidents, local military conflicts, some sports form a very numerous specific group of patients with craniocerebral injuries.

Aim - to develop a phototherapeutic hardware complex for the prevention, treatment and rehabilitation of vascular, inflammatory, degenerative, post-traumatic and other brain diseases that are difficult amenable to medical treatment including pharmacoresistant indomitable pain syndromes.

Materials and methods. The low-intensity electromagnetic radiation of the optical range of the spectrum and the magnetic field of a permanent magnet are physical factors that are used in phototherapeutic complex devices.

Results. A phototherapy apparatus complex has been developed for the prevention, treatment and rehabilitation of vascular, inflammatory, degenerative, post-traumatic and other brain diseases that are difficult to treat with drugs. The phototherapeutic hardware complex includes three devices: the modified photon-magnetic apparatus Korobov-Posokhov "Barva-CNS/FM", the photon-magnetic matrices A.Korobov - V.Korobov "Barva-Laryngologist/FM" and flexible photon-magnetic matrices A.Korobov - V.Korobov "Barva-Flex/24FM".

Conclusions. The presented clinical observations obtained using the developed phototherapeutic hardware complex for the treatment and prevention of diseases of the brain indicate high efficacy and safety of long-term low-intensity phototherapy in patients with dyscirculatory encephalopathy, with suffered ischemic and hemorrhagic strokes, with hypertensive disease.

Key words: phototherapy hardware complex, brain diseases, prevention, treatment, rehabilitation, electromagnetic radiation of the optical range of the spectrum, LEDs, magnets. 


\title{
ФОТОТЕРАПЕВТИЧНИЙ АПАРАТНИЙ КОМПЛЕКС ДЛЯ ПРОФІЛАКТИКИ, ЛІКУВАННЯ ТА РЕАБІЛІТАЦЇ̈ ЗАХВОРЮВАНЬ ЦЕНТРАЛЬНОЇ НЕРВОВОЇ СИСТЕМИ ЛЮДИНИ
}

\author{
А.М.Коробов ${ }^{1}$, М.Ф.Посохов ${ }^{2}$, В.А.Коробов ${ }^{3}$, О.В.Козир ${ }^{1}$ \\ ${ }^{1}$ Харківський національний університет імені В. Н. Каразіна, м. Харків, Украйна;

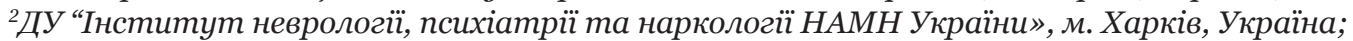 \\ ${ }^{3}$ Науково-виробнича медико-біологічна корпорація «Лазер і Здоров'я», м. Харків, Україна
}

Вступ. Значна поширеність судинних захворювань головного мозку, складність порушень функцій, ставлять проблеми їх лікування, реабілітації та профілактики в центр уваги сучасної неврології. У США кожні 45 секунд трапляється інсульт. Приблизно 750000 осіб на рік страждають від інсульту в США. За даними статистики МОЗ України, в країні щорічно фіксується понад 110000 первинних інсультів. Не менш серйозним захворюванням центральної нервової системи людини є хвороба Альцгеймера. Щороку від цієї хвороби помирає понад 500 тисяч американців, роблячи її третьою провідною причиною смерті в США. Дорожньо-транспортні пригоди, локальні військові конфлікти, деякі види спорту формують дуже велику специфічну групу пацієнтів з черепно-мозковими травмами.

Мета - розробка фототерапевтичного апаратного комплексу для профілактики, лікування та реабілітації судинних, запальних, дегенеративних, посттравматичних та інших захворювань головного мозку, які важко піддаються медикаментозному лікуванню.

Матеріали та методи. Низькоінтенсивне електромагнітне випромінювання оптичного діапазону спектра і магнітне поле постійного магніту - фізичні фактори, які використовуються в апаратах фототерапевтичного комплексу.

Результати. Розроблено фототерапевтичний апаратний комплекс для профілактики, лікування та реабілітації судинних, запальних, дегенеративних, посттравматичних та інших захворювань головного мозку, які важко піддаються медикаментозному лікуванню. Фототерапевтичний апаратний комплекс включає три апарати: модифікований фотонно-магнітний апарат Коробова-Посохова «Барва-ЦНС/ФМ», фотонно-магнітні матриці Коробова А.-Коробова В. «Барва-Ларинголог/ФМ» і гнучкі фотонно-магнітні матриці Коробова А.-Коробова В. «Барва-Флекс/24ФМ».

Висновки. Представлені клінічні спостереження, отримані з використанням розробленого фототерапевтичного апаратного комплексу для лікування і профілактики захворювань головного мозку, свідчать про високу ефективність та безпечність тривалої низкоинтенсивной фототерапії у хворих 3 дисциркуляторною енцефалопатією, з перенесеними ішемічними і геморагічними інсультами, з гіпертонічною хворобою.

Ключові слова: фототерапевтичний апаратний комплекс, захворювання головного мозку, профілактика, лікування, реабілітація, електромагнітне випромінювання оптичного діапазону спектра, світлодіоди, магніти.

\section{ФОТОТЕРАПЕВТИЧЕСКИЙ АППАРАТНЫЙ КОМПЛЕКС ДЛЯ ПРОФИЛАКТИКИ, ЛЕЧЕНИЯ И РЕАБИЛИТАЦИИ ЗАБОЛЕВАНИЙ ЦЕНТРАЛЬНОЙ НЕРВНОЙ СИСТЕМЫ ЧЕЛОВЕКА}

\author{
А.М.Коробов ${ }^{1}$, Н.Ф.Посохов ${ }^{2}$, В.А.Коробов ${ }^{3}$, Е.В.Козырь ${ }^{1}$ \\ ${ }^{1}$ Харьковский национальный университет имени В.Н.Каразина, г. Харьков, Украина; \\ ${ }^{2}$ ГУ “Институт неврологии, психиатрии и наркологии НАМН Украины”, г. Харьков, Украина; \\ ${ }^{3}$ Научно-производственная медико-биологическая корпорация «Лазер и Здоровъе», г. Харьков, Украина
}

Введение. Значительная распространенность сосудистых заболеваний головного мозга, сложность нарушений функций, ставят проблемы их лечения, реабилитации и профилактики в центр внимания современной неврологии. В США каждые 45 секунд случается инсульт. Примерно 750000 человек в год страдают от инсульта в США. По данным статистики Минздрава Украины, в стране ежегодно фиксируется более 110000 первичных инсультов. Не менее серьезным заболеванием центральной нервной системы человека является болезнь Альцгеймера. Каждый год от этой болезни умирает более 500 тысяч американцев, делая ее третьей ведущей причиной смерти в США. Дорожно-транспортные происшествия, локальные военные конфликты, некоторые виды спорта формируют весьма многочисленную специфическую группу пациентов с черепно-мозговыми травмами.

Цель - разработка фототерапевтического аппаратного комплекса для профилактики, лечения и реабилитации сосудистых, воспалительных, дегенеративных, посттравматических и других заболеваний головного мозга, которые трудно поддаются медикаментозному лечению, в том числе фармакорезистентных неукротимых болевых синдромов. 
Материалы и методы. Низкоинтенсивное электромагнитное излучение оптического диапазона спектра и магнитное поле постоянного магнита - физические факторы, которые используются в аппаратах фототерапевтического комплекса.

Результаты. Разработан фототерапевтический аппаратный комплекс для профилактики, лечения и реабилитации сосудистых, воспалительных, дегенеративных, посттравматических и других заболеваний головного мозга, которые трудно поддаются медикаментозному лечению. Фототерапевтический аппаратный комплекс включает три аппарата: модифицированный фотонно-магнитный аппарат Коробова-Посохова «Барва-ЦНС/ФМ», фотонно-магнитные матрицы Коробова А.-Коробова В. «Барва-Ларинголог/ФМ» и гибкие фотонно-магнитные матрицы Коробова А -Коробова В. «Барва-Флекс/24ФМ».

Выводы. Представленные клинические наблюдения, полученные с использованием разработанного фототерапевтического аппаратного комплекса для лечения и профилактики заболеваний головного мозга, свидетельствуют о высокой эффективности и безопасности длительной низкоинтенсивной фототерапии у больных с дисциркуляторной энцефалопатией, с перенесенными ишемическими и геморрагическими инсультами, с гипертонической болезнью.

Ключевые слова: фототерапевтический аппаратный комплекс, заболевания головного мозга, профилактика, лечение, реабилитация, электромагнитное излучение оптического диапазона спектра, светодиоды, магниты.

\section{Introduction}

Diseases of the central nervous system are rank among the top three leaders in the list of pathologies that have upsetting rates of the mortality, disablement for a long time and invalidization of patients. The significant prevalence of vascular diseases of the brain, the complexity of dysfunction, put the problems of their treatment, rehabilitation and prevention into the focus of attention of modern neurology.

The most formidable among the diseases of the central nervous system are vascular diseases of the brain. The Statistical Committee of the American Heart Association (AHA) shows that a stroke occurs in the United States every 45 seconds. This means that approximately 750,000 people a year suffer from a stroke in the United States. Of these cases, $87 \%$ are ischemic strokes, in which most people can be saved from death. The American Heart Association states that there are about 5.4 million people today who have had a stroke in the US. [1]

According to statistics from the Ministry of Health of Ukraine, more than 110,000 primary strokes are recorded annually in the country, after which death is registered in $37 \%$ of cases. More than $20 \%$ of patients become disabled, and only 10-20\% return to work. [2] Because of this, the rehabilitation of stroke patients is a serious medical and social problem for all countries.

Timely, pathogenetically directed therapy at the stage of reversible defects in the acute period of stroke and in case of chronic inefficiency of cerebral circulation is the most promising direction in modern approaches to the treatment of this disease. Today's advances in surgery and pharmacotherapy in the treatment of stroke in the acute period are indisputable. However, at the stage of rehabilitation of patients with stroke, as well as for the prevention of this pathology, it is impossible to do without physiotherapy. And here, the undisputed leader is phototherapy (photobiomodulation), in which the low-intensity electromagnetic radiation of the visible and infrared ranges of the spectrum of various sources (lasers, LEDs, gas discharge lamps, incandescent lamps, etc.) is used as a therapeutic factor. [3,4,5,6 ]

No less serious disease of the human central nervous system is Alzheimer's disease - a common chronic, expensive, debilitating neurodegenerative disease characterized by progressive loss of memory and cognitive disfunction. Alzheimer's disease is currently observed in 5.4 million Americans [7]. According to forecasts, in the next 20 years, every fourth inhabitant of the United States will have a diagnosis: Alzheimer's disease. Each year, more than 500,000 Americans die from this disease, making it the third leading cause of death in the United States $[8,9]$. Worst of all, there is no effective medicine for this disease.

The first researches conducted in a number of scientific and practical centers showed the perspective of using low-intensity electromagnetic radiation of the red and infrared ranges of the spectrum (photobiomodulation) to treat Alzheimer's disease [10,11]. A group of patients who were treated for Alzheimer's disease using photonic technology had improved cerebral microcirculation leading to a permanent (from 1 to 7 years) reduction of dementia and reconstruction of cognitive functions [12,13].

Traffic accidents, local military conflicts, some sports form a very numerous specific group of patients with craniocerebral injuries. Today, researches on the use of photobiomodulation for treating patients with craniocerebral injuries are usually few, but the results shows that restoration of microcirculation, rheological properties of blood, immunomodulatory and anti-inflammatory effect of photobiomodulation may be effective in treating these patients $[11,14,15,16]$.

The aim of this work was to develop a phototherapeutic hardware complex for the prevention, treatment and rehabilitation of vascular, inflammatory, degenerative, post-traumatic and other brain diseases that are difficult amenable to medical treatment including pharmacoresistant indomitable pain syndromes. 


\section{Materials and methods}

Scientifically proven fact is the assertion that almost all pathological processes in the human body begin with the first, non-specific phase - a defect of the microcirculation of blood $[17,18]$.

It is natural to assume that any treatment process of any pathology, including neurological, should begin with the reconstruction of microcirculation of blood.

This problem is perfect solved by phototherapy (photobiomodulation). The universalism of the therapeutic effect of light is based on its ability to exert a powerful regulating effect on the main physiological link of the body's activity - the microcirculation of blood and lymph [19]. The light of the visible and infrared ranges of the spectrum normalizes the work of the regulatory systems of the human body (immune, endocrine and central nervous) $[20,21,22]$.

Under the action of visible and infrared light, the elasticity of blood vessel walls increases, the red blood cell elasticity increases, the oxygen transport function of the blood increases, the activity of cell membranes increases, angenesis accelerates, lipid peroxidation decreases, the rheological blood parameters are normalized, the formation of ATP in mitochondria is reduced, which increases the bioenergy potential of cells [23]. The light has an anti-inflammatory, anti-edema, healing and analgesic effect, normalizes blood pressure, has a radioprotective and photoreactivating effect [24].

The light has no contraindications and negative side effects and can be used to treat and prevent the most common human diseases, including oncological ones. The end result of exposure to the light of the visible and infrared ranges of the spectrum is an increase of the resistance of the organism and an expansion of the limits of its adaptation, i.e. resistance to various diseases [25].

On the basis thereof, more than 10 years ago, the "Barva-CNS" Posokhov-Korobov unit was developed for phototherapy of diseases of the central nervous system [26] by transcranial exposure to the human brain. The unit consists of two blocks - a photonic block and block of power and control. The photonic block of the units was made in the form of a helmet. Geometrical size of the helmet were chosen in such a way that LED irradiators could affect the entire area of the hairy part of the patient's head. The first units used light sources emitting in the red and infrared regions of the visible spectrum. This radiation invades biological tissues as deeply as possible. The long-term experience of using "Barva-CNS" units in clinical practice has shown that in most cases a good, stable result of treatment is achieved. Particularly high efficiency is observed when using of the unit for the rehabilitation and prevention of neurological diseases in sanatorium-resort practice.

The second important physical factor used in physiotherapy is the constant magnetic field. It has both direct and reflex effects on various organs and systems. The basis of the action of the magnetic field on the body are the primary physical and chemical changes that appear in various biological structures under its influence. By causing a building of the liquid crystal structures of biological membranes and intracellular biological structures, static magnetic fields affect their functional activity [27].

The magnetic field, affecting the human body, leads to the following effects:

- changes biochemical and biophysical processes with the subsequent normalization of cell membrane permeability and acceleration of redox reactions;

- changes the rate of flow of free radical reactions and hydration of ions;

- improves the rheological qualities of blood;

- stimulates the opening of the reserve capillaries;

- stimulates tissue regeneration;

- reduces the formation of metHb, which improves tissue respiration;

- changes the conformation and orientation of macromolecules;

- changes the physical and chemical properties and structure of water;

- improves the condition of the vascular endothelium;

- eliminates vegetovascular disorders;

- has anti-inflammatory and analgesic effect.

These properties of light and magnetic field determine their high efficiency in the treatment and prevention of the absolute majority of human diseases.

\section{Results}

In view of the foregoing, we have developed a phototherapy hardware complex, which allows treatment of the most common and orphan diseases of the brain by exposure to infrared and visible spectral radiation in combination with a constant magnetic field.

\section{Modified photon-magnetic apparatus}

Korobov-Posokhov "Barva-CNS/FM"

The base apparatus of the phototherapeutic hardware complex for the rehabilitation, prevention and treatment of diseases of the human central nervous system is the modified photon-magnetic apparatus Korobov-Posokhov "Barva-CNS/FM". The previous model of the device for phototherapy of diseases of the central nervous system of Posokhov-Korobov "Barva-CNS", described in detail in the work [26], has undergone significant changes.

First, the spectral range of the emitting LEDs of the photon block has expanded in the direction of short wavelengths up to $400 \mathrm{~nm}$. The expediency of such a step is due to the need to incorporate molecules into the photochemical processes, which also absorb in the short-wave region of the visible spectrum. In this case, receptors that absorb in the red region of the spectrum, receive an additional portion of energy due to the effect of phototransformation of shortwave radiation into the 
longwave wavelength, which we observed in the tissues of the organism of animals and humans and which was described by us earlier [28].

The second significant change in the previous model of the device was the inclusion of the magnetic field of permanent magnets as an additional physical factor that has a therapeutic effect on the human central nervous system. At the same time, the bone tissues do not prevent the penetration of the magnetic field into the brain tissue, which increases the degree of influence of this factor in the transcranial effect on the patient's brain.

Externally, the photon block of the new device is almost the same as its predecessor. The base of the block, still, has the shape of a helmet, but is made of a more wear-resistant material. In addition, currently the photon block has three base sizes ("S", "M", "L").

The radiation zones of the photon block of the new apparatus are also divided into central 1 , frontal-temporal (right and left) 2 and cervico-occipital (right and left) 3 and are shown in Fig. 1. LEDs emitting in different spectral ranges are combined in series into chains. The chains of LEDs uniformly fill each radiation zone so that the distance between adjacent LEDs is in the range of $18-25 \mathrm{~mm}$. The maximums of the emission

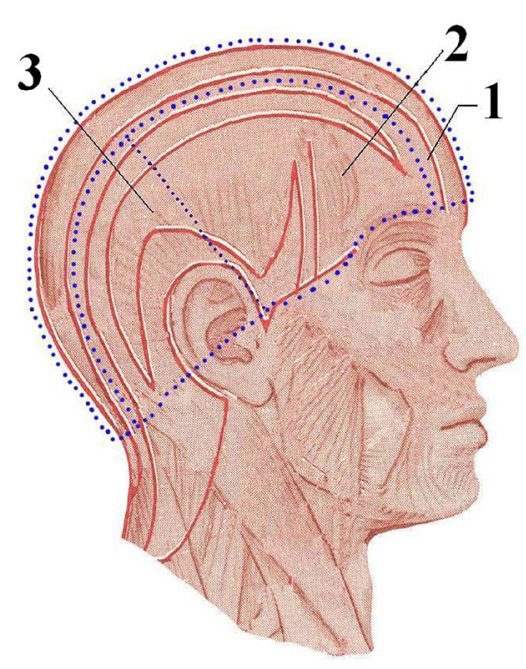

Fig. 1. Schematic division into zones of the photon block of the «Barva-CNS» device and the corresponding biologically active zones

bands of the LEDs used in the "Barva-CNS" devices correspond to the following wavelengths: $940 \mathrm{~nm}$ (infrared radiation), $630 \mathrm{~nm}$ (red radiation), $525 \mathrm{~nm}$ (green radiation), $470 \mathrm{~nm}$ (blue radiation) and $405 \mathrm{~nm}$ (violet radiation). The emission bandwidth of each LED is $25-30 \mathrm{~nm}$ in terms of half-intensity radiation. The radiation power of each LED is in the range of $2-5 \mathrm{~mW}$. The number of LEDs varies from 215 pieces (size "S") to 285 pieces (size "L").

Each radiation zone has an independent power supply channel connected to the switch. The switch allows you to connect the power to the radiation zones in any combination (from one to all at the same time), depending on the problem being solved. The power supply and control unit "Barva MPB-5S/800" was developed and manufactured by the Laboratory of Physical and Biomedical Electronics of the National Technical University "Kharkiv Polytechnic Institute" according to the technical specifications of the Scientific and Production Medical-Biological Corporation "Laser and Health". In the new model of the device is provided its power from the battery (for example, Power Bank).

\section{Photon-magnetic matrices A. Korobov-V. Korobov "Barva-Laryngologist/FM"}

The use of the "Barva-CNS/FM" photon-magnetic apparatus for transcranial photobiomodulation of brain pathologies is a necessary, but not always sufficient condition for achieving a good result. As already mentioned in the introduction, in the event of a lesion in deep areas of the brain, the blood entering these parts of the brain should be photomodified. To solve this problem, the photon-magnetic matrix of A. Korobov-V. Korobov "Barva-Laryngologist/FM" is included in the composition of the phototherapeutic hardware complex. The simplest and most convenient way to photomodify blood entering the brain is transcutaneous irradiation in the carotid arteries.

To achieve this goal, the base of the matrix "Barva-Laryngologist/FM" is structurally made of a flexible material in the form of a rectangular strip with a size of $530 \times 70 \mathrm{~mm}$ (adapted for optimal irradiation of the human neck). On the basis of installed 84 LEDs (14 groups of 6 LEDs in the group). Each group of LEDs is connected in series in a chain. The LEDs are equidistant at a distance of $18 \mathrm{~mm}$ from each other. Permanent magnets with special holders are mounted on LEDs. Technical parameters and characteristics of LEDs and magnets are the same as in the device "Barva-CNS/PH".

The photon-magnetic matrices of A. Korobov-V. Korobov "Barva-Laryngologist/FM" (Fig. 2) are powered either from a battery (for example, Power Bank) or from an adapter that converts a network alternating current of $220 \mathrm{~V}, 50 \mathrm{~Hz}$ to a direct current of $14 \mathrm{~V}$.

In Fig. 3 shows a photo of the "Barva-CNS/FM" apparatus and the "Barva-Laryngologist/FM" matrix mounted on a mannequin in the working position.

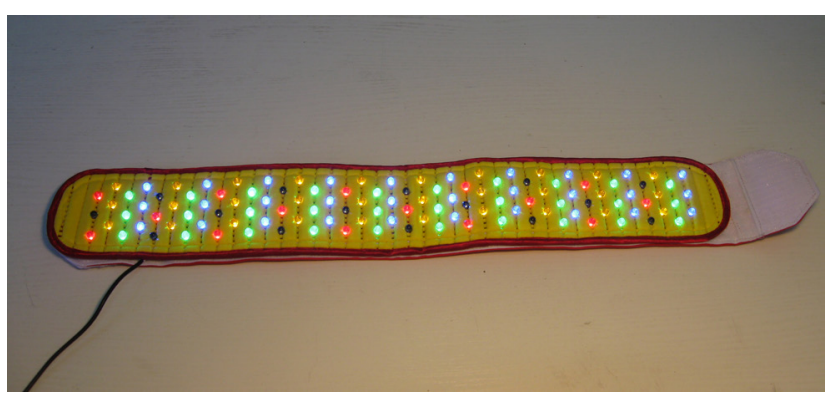

Fig. 2. Photon-magnetic matrix A. Korobov-V. Korobov "Barva-Laryngologist/FM" 
The "Laser and Health" Corporation of the "Barva-Laryngologist/FM" matrix produces three standard sizes: $480 \times 70 \mathrm{~mm}$ ("S"), $530 \times 70 \mathrm{~mm}$ ("M") and $580 \times 70 \mathrm{~mm}$ ("L”).

Flexible photon-magnetic matrices A. Korobov-V. Korobov "Barva-Flex/24FM"

One of the most versatile personal medical devices for light therapy, developed by us and produced by Laser and Health Corporation, are the flexible photon-magnetic matrices of A. Korobov-V. Korobov "Barva-Flex/24FM" the design of which is described in detail in [29]. The inclusion of these matrices in the composition of the phototherapeutic hardware complex for the treatment and prevention of diseases of the brain is due to their ability to have a normalizing effect on the

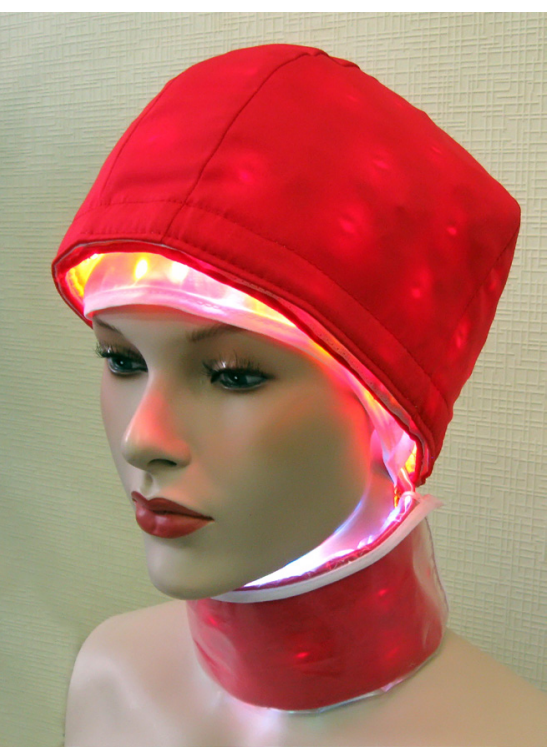

Fig. 3. Apparatus Korobov-Posokhov "Barva-CNS/FM" and matrix A. Korobov-V. Korobov "Barva-Laryngologist/FM"

A distinctive feature of photon matrices is that they have a flexible base. This allows the matrices to repeat the shape of that part of the human body to which they are applied, which ensures the most efficient transmission of LED radiation without reflecting losses at the air-skin interface.

The basic version of the matrix, shown schematically in Fig. 4, 5 contains 24 LEDs, located equidistantly in 4 rows of 6 LEDs in each row. Special matrices have an arrangement of $3 \times 8$ and $2 \times 12$ LEDs (to illuminate the spine and paravertebral zones).

The photon matrix "Barva-Flex" is a plate 1 with two lugs 2 and 3, designed for attaching elastic belts that allow fixing the matrix on the patient's body. The matrix is made of hypoallergenic medical immune, endocrine, central and peripheral nervous rubber and does not cause irritation of the skin. The systems. Such tactics of treatment, prevention and power supply of the LEDs 4 is supplied from the power rehabilitation gives the fastest and most stable result. source using a cable 5 with a connector 6 (Fig. 4).

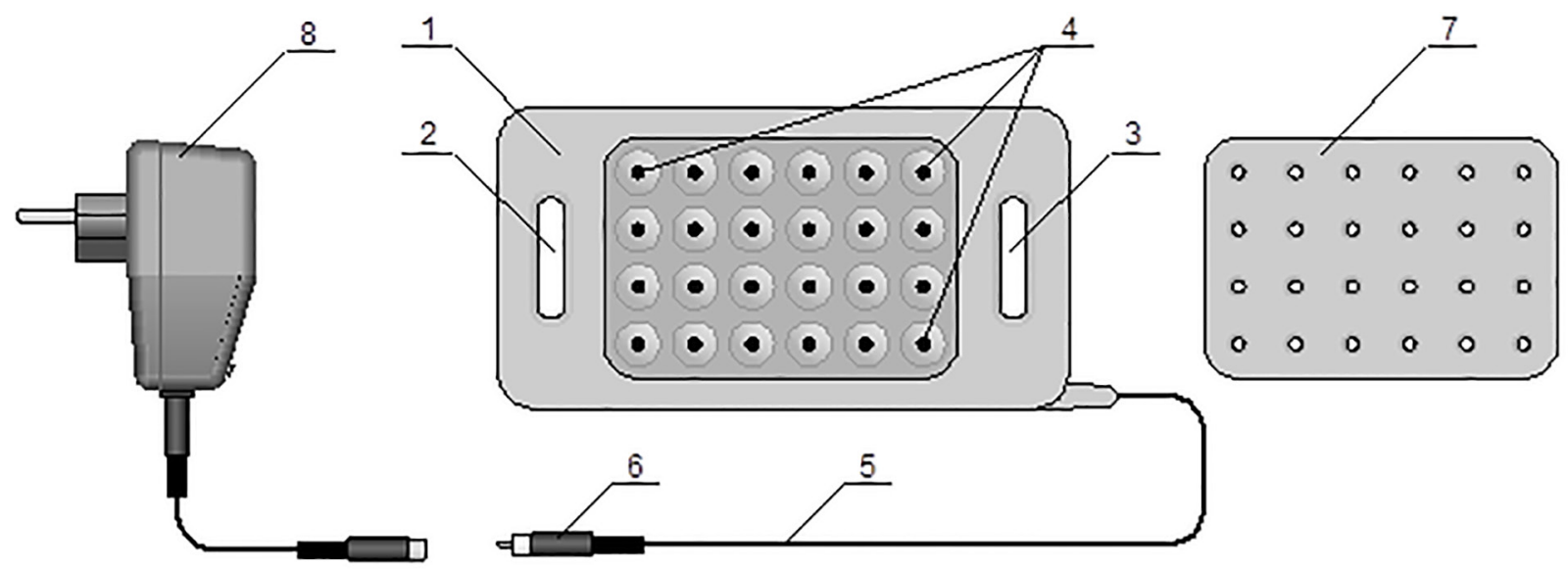

Fig. 4. Schemes of the photon and magnetic matrices "Barva-Flex/24FM"
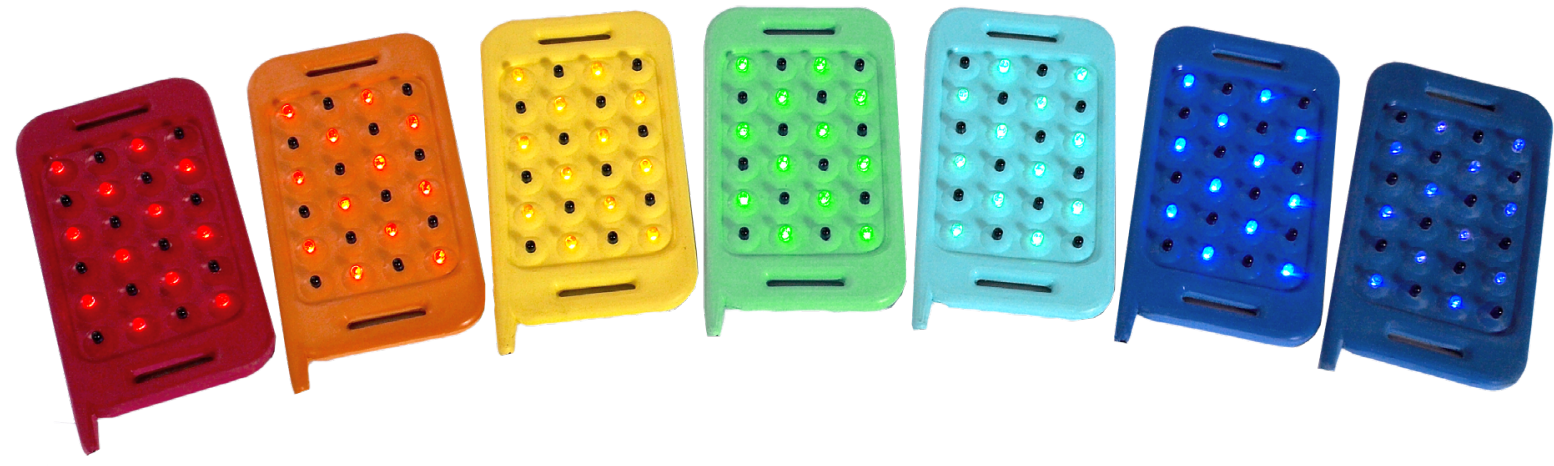

Fig. 5. Photon matrices A. Korobov-V. Korobov "Barva-Flex/24FM" 
If necessary, the combined effect of electromagnetic radiation in the infrared and visible parts of the spectrum with a constant magnetic field on the photon matrix is set the magnetic matrix "Barva-Flex/Mag" 7 (Fig. 4).

The main technical data of the photon matrix "Barva-Flex" and the magnetic matrix "Barva-Flex/Mag" are given in Table 1.

The observance of sanitary and hygienic requirements is ensured through the use of disposable transparent plastic bags for food of appropriate sizes, which from a specially designed two-channel microprocessor pulse control unit "Barva MPB-2S/80".

The pulsed control unit "Barva MPB-2S/80" ensures the operation of photon matrices in continuous, pulsed or scanning modes (scanning is performed according to the modulation frequency of the luminous flux). The control unit contains a timer that provides the dosing of exposure for the duration of exposure. Two flexible photon-magnetic matrices can be connected to the control unit at the same time.

When the control unit operates in continuous Table 1

Technical data of the photon and magnetic matrices "Barva-Flex"

\begin{tabular}{|c|c|c|}
\hline Parameter name & Units & Value \\
\hline The number of LEDs in the photon matrix & pieces & 24 \\
\hline Radiation power of each LED & $\mathrm{mVt}$ & 5 \\
\hline Supply voltage & $\mathrm{V}$ & 14 \\
\hline Overall dimensions of the basic version of the photon matrix "Barva-Flex", not more & $\mathrm{mm}$ & $190 \times 98 \times 15$ \\
\hline The number of ring magnets in the magnetic matrix & pieces & 24 \\
\hline Magnetic induction of each magnet & $\mathrm{mTI}$ & 200 \\
\hline Overall dimensions of the magnetic matrix "Barva-Flex/Mag", not more & $\mathrm{mm}$ & $120 \times 80 \times 7$ \\
\hline
\end{tabular}

are worn on the matrix. In case of contamination, the surface of the matrix can be treated with a solution of washing powder and disinfected with a $70 \%$ solution of ethyl alcohol.

The placement of photon matrices in relation to the patient's body is distant, contact and contact with compression. In the distant mode of irradiation, the matrix is located at some distance from the body, as a result of which 5-10\% of light is reflected from its surface. In the case of distant use of matrices, the latter can be hardened in special holders one or several pieces to ensure the possibility of covering large surfaces, for example, extensive burns. With the contact method of irradiation, almost all of the light is absorbed by the tissues of the body, in which it is distributed according to the laws of nonlinear optics due to tissue heterogeneity. In this case, the photon matrix is fixed on the desired part of the patient's body, either with the help of an elastic tape, or with the help of "Velcro".

When the tissues are compressed by the photon matrix, the greatest penetration depth is achieved for light of a given wavelength. In addition, due to the compaction of tissues, the degree of radiation divergence decreases, i.e. his dissipation. Compression of tissues is provided either by the patient's body itself (lie down on the matrix) or by fixing the matrix with pressure bandages.

The flexible photon-magnetic matrices of A. Korobov-V. Korobov "Barva-Flex/24FM" are powered either from a battery (for example, Power Bank) or from an adapter that converts a network alternating current of $220 \mathrm{~V}, 50 \mathrm{~Hz}$ to a direct current of $14 \mathrm{~V}$, or mode, the radiation from the phototherapeutic device's LEDs will be continuous, and the radiation power will be maximum. In the pulsed and scanning modes at any modulation frequency, the duty cycle of the output voltage of the control unit will be 2 (the pulse duration is half the period), and the average radiation power of the phototherapy device will be two times less than in continuous mode.

The inclusion of photon-magnetic matrices A. Korobov-V. Korobov "Barva-Flex/FM" into the phototherapy hardware complex for the treatment and prevention of diseases of the central nervous system is due to the high efficiency of their use for many years for the treatment and prevention of cardiovascular diseases, including myocardial infarction and stroke [30]; for the rehabilitation of post-infarction and poststroke conditions, as well as for the normalization of high or low blood pressure [31,32]. The timely, during the first two hours after a heart attack or stroke, the use of the "Barva-Flex/FM" photon-magnetic matrix increases the likelihood of a favorable outcome of the treatment of these diseases by at least $80 \%$, as the rheological parameters of the blood normalize under the action of light.

In addition, flexible photon-magnetic matrices are used with high efficiency for the treatment and prevention of respiratory diseases $[33,34,35]$, diseases of the gastrointestinal tract $[36,37,38]$, diseases of the musculoskeletal system $[39,40,41]$, infectious diseases $[42,43,44]$ and many others. This implies the expediency of using the "Barva-Flex/FM" flexible photon-magnetic matrices for treating of patients with diseases of the central nervous system in comorbid conditions. 
Experience of using the phototherapeutic hardware complex in the treatment of vascular diseases of the cerebrum

Below are the data of practical application of the above-mentioned devices in the Novoushytsky Territorial Center for Social Services (Khmelnitsky region, Ukraine) [45 ].

Example 1. Patient Svetlana K., born on 1966.

Diagnosis: dyscirculatory encephalopathy.

Phototherapy: the patient received 14 treatment sessions using the "Barva-CNS/PH" apparatus. Procedures were carried out daily for 15 minutes in fractional doses ( 5 minutes irradiation, 5 minutes break). The patient noted improvement on the third day after the start of treatment.

Example 2. Patient Lidia K., born on 1936.

Diagnosis: dyscirculatory disease with hypertension; chronic insufficiency of cerebral circulation II st.

Phototherapy: the patient received 14 daily treatment sessions with the help of the "Barva-CNS/PH" apparatus. The patient notes improved sleep, reduced headache.

Example 3. Patient Antonina G., born on 1952.

Diagnosis: osteochondrosis of the cervical spine with severe pain; chronic insufficiency of cerebral circulation II st.

Phototherapy: the patient received 14 daily treatment sessions using the "Barva-CNS/PH" apparatus and the "Barva-Laryngologist/PH" matrix. The patient notes improvement in general condition, reduction of headache and neck pain.

The results of complex treatment with the involvement of phototherapy devices allow us to conclude that the positive effect of phototherapy in vascular diseases of the brain.

Experience of using phototherapeutic hardware complex for the rehabilitation of post-stroke conditions (Gorodotsky territorial center of social services, Khmelnytsky region, Ukraine) [46,47]

Example 1. Patient Evgenia F.,born on 1951, pensioner, invalid of group II 3/3.

Diagnosis: condition after suffering ischemic stroke, hypertensive disease III st., angina pectoris 2 st. Infractions: headaches, blinking in eyes, dizziness.

The treatment was carried out using the "Barva-CNS/PH" photon-magnetic apparatus Korobov-Posokhov according to a technique developed by the authors of the apparatus (seven daily procedures lasting 10-15 minutes) and the photon-magnetic matrix A. Korobov-V. Korobov "Barva-Laryngologist/FM" (fourteen daily procedures lasting 15-30 minutes).

Treatment result: flicker in the eyes disappeared, dizziness disappeared and headaches decreased.

Example 2. Patient Vladimir P., born on 1954, pensioner.

Diagnosis: condition after suffering a hemorrhagic stroke (July 2017), left-sided hemiparesis, thalamic pain syndrome.
Complaints: sensitivity in the left upper and lower extremities is impaired, the muscle tone of the left upper and lower extremities is reduced, constant, intermittently burning pains in the left extremities and in the left half of the body, in the left half of the face; the patient moves with the help of crutches.

The treatment was carried out for two weeks (daily) with the help of the devices listed above according to the procedures given in the instructions for the devices.

Results: the patient's condition is satisfactory, reduced severity of pain by $50 \%$, the sensitivity of the left lower and upper extremities has improved, the muscle tone has decreased, the patient moves with the help of a stick.

Example 3. Patient Valery S., born on 1973, unemployed, disabled person of group I.

Diagnosis: sustained effects of ischemic stroke (2016), right hemiparesis, aphasia.

Complaints: lack of free movements of the right upper and lower extremities, sensitivity in the right upper and lower extremities, periodic headaches.

The treatment was carried out with photon matrices "Barva-Flex/FM24", "Barva-TsNS", "Barva-Laryngologist" according to the methods given in the instructions for the devices.

The result of the treatment: the patient's condition is satisfactory, the sensitivity of the lower limbs has improved, the number and duration of headaches has decreased.

\section{Successful treatment of dyscirculatory encephalopathy with the help}

of phototherapy complex (case from practice) [48]

Under our supervision there is a patient of 72 years, suffering for many years with coronary artery disease, atherosclerotic cardiosclerosis, grade III hypertension, chronic hepatosis, small-focal pancreatic fibrosis, saline diathesis, diffuse pneumosclerosis. Since June 2012, the patient has been experiencing transient ischemic attacks (TIA) in the vertebro-basilar basin, clinically manifested by headaches, dizziness, nausea and vomiting, aggravated by a change in body position. In the neurological status - symptoms of damage to the brain stem and cerebellum.

In February 2014 (after the next TIA) a spiral computed tomography of the brain was performed. Identified multiple foci in the brain with a diameter of $10 \mathrm{~mm}$, located subcortical, moderate external and internal subatrophic hydrocephalus. Taking into account the fact that neuro-ophthalmologic examination revealed signs of CSF in the form of blurred visual nerve disk boundaries and congestion of the retinal vein veins, the secondary nature of the pathological foci in the brain was not excluded..

The patient, on her own initiative, spent almost 7 to 10 five-minute light therapy sessions for 7 months using a Korobov-Posokhov polychrome photon matrix "Barva-CNS/HR", which ensured transcranial light effects on the surface layers of the brain. Simultane- 
ously with the transcranial light exposure, the patient performed a transcutaneous luminescence of the carotid arteries using radiation from the photon matrix A. Korobov-V. Korobov "Barva-Laryngologist/HRP”. The duration of each procedure was 10-15 minutes.

During this time, the general condition of the patient improved progressively. In the neurological status, almost complete regression of pathological neurological symptoms is noted.

In April 2014, MRI in the white matter of the frontal and parietal lobes was determined by multiple foci ranging in size from 3 to $10 \mathrm{~mm}$, hyperintense on T2VI and FLAIR. In addition, a decrease in the mp-signal at T2 GRE from leptomenegeal membranes of the right parietal region and convexital regions of the left cerebellar hemisphere was determined; expansion of the lateral and third ventricles.

In the control neurological examination in October 2014, the presence of microsymptomatics characteristic of dyscirculatory encephalopathy was noted. With SCT and MRI (1.5 T), no focal changes in the brain substance were detected. At the same time, the presence of external-internal subatrophic hydrocephalus is noted. Thus, in dynamics, neuroimaging techniques showed regression of foci in the white matter of the brain.

\section{Conclusions}

1. A phototherapy apparatus complex has been developed for the prevention, treatment and rehabilitation of vascular, inflammatory, degenerative, post-traumatic and other brain diseases that are difficult to treat with drugs, including pharmacoresistant pain syndromes. The phototherapeutic hardware complex includes three devices: the modified photon-magnetic apparatus Korobov-Posokhov "Barva-CNS/FM", the photon-magnetic matrices A. Korobov-V. Korobov "Barva-Laryngologist/FM" and flexible photon-magnetic matrices A. Korobov-V. Korobov "Barva-Flex/24FM".

2. The main indications for phototherapy with the help of phototherapeutic hardware complex, in our opinion, can be:

- acute and chronic circulatory disorders of the brain: acute ischemic strokes, transient cerebral circulatory disorders (including in terms of emergency care), cerebral arteriosclerosis, cerebral vascular atherosclerosis, dyscirculatory atherosclerotic and hypertensive encephalopathy; effects of ischemic and hemorrhagic strokes;

- neurodegenerative diseases of the brain: parkinsonism, Alzheimer's disease, Wilson-Konovalov disease, etc.;

- acute traumatic brain injury and its consequences;

- acute and chronic inflammatory diseases of the brain (arachnoiditis, encephalitis, meningoencephalitis);

- headaches of various genesis;
- neuropathy, neuralgia and neuritis of cranial nerves;

- neurosis and neurosis-like states, sleep disorders, jet lag;

- chronic fatigue syndrome;

- diabetic, hypertensive and atherosclerotic angiopathy of the retina;

- osteochondrosis of the upper cervical spine;

- esidual effects and consequences of ischemic and hemorrhagic strokes;

- preoperative preparation and postoperative rehabilitation of patients with the consequences of previously transferred neurological and neurosurgical pathology.

3. The presented clinical observations obtained using the developed phototherapeutic hardware complex for the treatment and prevention of diseases of the brain indicate high efficacy and safety of long-term low-intensity phototherapy in patients with dyscirculatory encephalopathy, with suffered ischemic and hemorrhagic strokes, with hypertensive disease.

4. Comprehension of the described observations naturally leads to the conclusion that it is necessary to conduct detailed basic research on the study of the laws and mechanisms of action of low-intensity electromagnetic radiation of different spectral ranges and a constant magnetic field on the regeneration of the nervous tissue of the brain and peripheral nerves.

\section{References}

1. Boonswang NAb, Chicchi M, Lukachek A, Curtiss D. A new treatment protocol using photobiomodulation and muscle /bone/ joint recovery techniques having a dramatic effect on a stroke patient's recovery: a new weapon for clinicians. BMJ Case Reports. 2012. DOI:10.1136/ bcr.08.2011. 4689.

2. Sapon NA, Guk AP, Nikiforova AN, et al. Stroke. The realities and needs of providing neurosurgical care in Ukraine. Ukr. neyrohirurgich. jurnal [Ukr. neurosurg. journal]. 2013;4:43-8. (in Russian)

3. Samosyuk IZ, Samosyuk NI, Fedorov SN. Transcranial methods of physiotherapy in the medical rehabilitation of post-stroke patients Praktichna angiologiya. [Practical angiology]. 2010;5,6(34,35). (in Russian)

4. Lampl Y. Laser treatment for stroke. Expert Rev Neurotherapy. 2007;7:961-5.

5. Lampl Y, Ziviv JA, Fisher M. Infrared therapy for ischemic stroke: a new treatment strategy. Stroke. 2007;38:1843-9.

6. Hashmi JT, Huang Y, Sharma BZ, Naeser MA, Hamblin MR. Role of Low-Level Laser Therapy in Neurorehabilitation. PM R. Author manuscript; available in PMC 2011 Dec 1. PM R. 2010 December. 2 (12 Suppl 2): S292-S305. doi:10.1016/j.pmrj.2010.10.013.

7. Alz.org, 2016 Disease Facts and Figures.

8. Neurology March 5, 2014 [Epub ahead of print].

9. Time Magazine March 5, 2014.

10. Lim L. The Potential of Treating Alzheimer's disease with Intranasal Light Therapy. Toronto: Medic Lights Research Inc. 2013. 
11. Hennessy M, Hamblin MR. Photobiomodulation and the brain: a new paradigm. J Opt. 2017 January;19(1): 013003-doi:10.1088/2040-8986/19/1/013003.

12. Maksimovich IV. Dementia and Cognitive Impairment Reduction after Laser Transcatheter Treatment of Alzheimer's Disease. World J Neurosci. 2015; 5.

13. Berman MH, Halper JP, Nichols TW, Jarrett H, Lundy A, Huang JH. Photobiomodulation with Near Infrared Light Helmet in a Pilot, Placebo Controlled Clinical Trial in Dementia Patients Testing Memory and Cognition. J Neurol Neurosci. 2017; 8(1): doi:10.21767/21716625.1000176.

14. Naeser MA, Zafonte R, Krengel MH, Martin PI, Frazier J, Hamblin MR, Knight JA, Meehan WP 3rd, Baker EH. Significant improvements in cognitive performance post-transcranial, red/near-infrared light-emitting diode treatments in chronic, mild traumatic brain injury: open-protocol study. J Neurotrauma. 2014;31:1008-17.

15. Naeser MA, Martins PI, Ho MD, Krengel MH, Bogdanova Y, Knight JA, Yee MK, Zafonte R, Frazier J, Hamblin MR, Koo BB. Transcranial, red/nearinfrared light-emitting diode therapy to improve cognition in chronic traumatic brain injury. Photomed Laser Surg. 2016;34(12):610-26.

16. Wu Q, Huang Y-Y, Dhital S, et al. Low level laser therapy for traumatic brain injury. SPIE Proc. 2010;7552:755206-8.

17. Maksimenko VA. Tipovyie narusheniya perifericheskogo krovoobrascheniya i mikrotsirkulyatsii. Uchebnoe posobie [Typical disorders of peripheral circulation and microcirculation. Study guide]. Blagoveschensk; 2013. (in Russian)

18. Litvitskiy PF. Patofiziologiya: ucheb. dlya vuzov [Pathophysiology: studies. for universities]. 4th ed., Moscow: GEOTAR-Media Publ; 2007. 496 p. .(in Russian)

19. Maslova MG, Chertok VM, editors. Nizkoenergeticheskie lazeryi v eksperimente i klinike [Low-energy lasers in experiment and clinic]. Vladivostok: Izdatelstvo Dalnevostochnogo. universiteta Publ.; 1990. 248 p. .(in Russian)

20. Kozlov VI, Buylin VA, Samoylov NG, Markov II. Skobelkina OK, editors. Osnovyi lazernoy fizio- i refleksoterapii [Basics of laser physio- and reflexotherapy]. Samara-Kiev; 1993.216 p. (in Russian)

21. Gotovskiy YUV, Vyisheslavtsev AP, Kosareva LB, et al. Tsvetovaya svetoterapiya [Color light therapy]. Moscow: IMEDIS Publ; 2001. 432 p. (in Russian)

22. Konev SV, Volotovskiy ID. . Fotobiologiya [Photobiology]. Minsk: : Izdatelstvo BGU im. V.I.Lenina Publ; 1979. 383 p. (in Russian)

23. Vladimirov YuA, Osipov AN, Klebanov GI. Photobiological basis of therapeutic use of laser irradiation. Biohimiya [Biochemistry]. 2004;69(1):103-13. (in Russian)

24. Kaminskiy AV. The use of laser radiation as a stimulating factor of proliferative processes in bone grafting defects. In: . Materialyi XXIII Mejdunarodnoy nauchno-prakticheskoy konferentsii. Primenenie lazerov v meditsine i biologii [Proceedings of the XXIII International Scientific and Practical Conference. The use of lasers in medicine and biology]; 2005 May 25-28; Nikolaev. Kharkov: NPMBK "Laser and Health" Publ; 2005, p. 31-32. (in Russian)

25. Tondiy LD, Korobov AM. The use of the Korobov photon matrix "Barva-Flex / K" to stimulate physiological measures to protect the body. In: Materialyi XVI Mejdunarodnoy nauchno-prakticheskoy konferentsii. Primenenie lazerov v meditsine i biologii [Materials of the XVI International Scientific and Practical Conference. The use of lasers in medicine and biology]; 2001 Sept 25-28; Theodosius. Kharkov: NPMBK Laser and Health Publ; 2001, p. 28-29. (in Russian)

26. Posohov NF, Kozyir EV, Korobov AM, Chernenkov VG, Serbinenko IA. The Korobov-Posokhov apparatus for phototherapy of diseases of the central nervous system "Barva-CNS". Fotobiologiya i Fotomeditsina [Photobiology and Photomedicine]. 2007;5(3,4):109-15. (in Russian)

27. Ulaschik VS, editor et al. Minsk: : Belaruskaya navuka Publ; 2015. 379 p. (in Russian)

28. Korobov AM. About photoluminescence of biological objects under the action of low-intensity electromagnetic radiation of the visible spectrum. In: Materialyi XXXXI Mejdunarodnoy nauchno-prakticheskoy konferentsii. Primeneniya lazerov v meditsine i biologii [Proceedings of the XXXXI International Scientific Practical Conference. The use of lasers in medicine and biology]; 2014 May 28-31; Kharkiv. Kharkiv: NPMBK Laser and Health Publ; p. 8-11. (in Russian)

29. Korobov AM, Korobov VA. Photon-magnetic matrices Korobov A. - Korobov V. "Barva-Flex/FM24". Fotobiologiya i Fotomeditsina [Photobiology and Photomedicine]. 2012;9(1,2):132-42. (in Russian)

30. Grigorova IA, Eskin AR, Nekrasova NA. The rationale for the use of the matrix "Barva-Flex" in patients with dyscirculatory encephalopathy. In: Materialyi XXV Mejdunarodnoy nauchno-prakticheskoy konferentsii. Primenenie lazerov v meditsine i biologii [Proceedings of the XXV International Scientific and Practical Conference. The use of lasers in medicine and biology]; 2006 May 24-28; Lutsk. Kharkiv: NPMBK Laser and Health Publ; 2006, p. 20-1. (in Russian)

31. Tondiy LD, Lesnaya TA, Zhuravlev VA, et al. Experience of using the Korobov Barva-Flex photon matrices to normalize blood pressure. In: Materialyi XXVI Mejdunarodnoy nauchno-prakticheskoy konferentsii. Primenenie lazerov v meditsine i biologii [Proceedings of the XXVI International Scientific and Practical Conference. The use of lasers in medicine and biology]; 2006 Oct 11-14; Yalta. Kharkov: NPMBK Laser and Health Publ; 2006; p. 37-8. (in Russian)

32. Tondiy LD, Lesnaya TA, Zhuravlev VA, et al. The role of phototherapy in the rehabilitation of post-infarction patients. In: Materialyi XXVIII Mejdunarodnoy nauchno-prakticheskoy konferentsii. Primenenie lazerov v meditsine i biologii [Proceedings of the XXVIII International Scientific and Practical Conference. The use of lasers in medicine and biology]; 2007 October 21-24; Yalta. Kharkov: NPMBK Laser and Health Publ; 2007, p. 53-5. (in Russian)

33. Gorbunova EM, Zasimskaya VA. Application of phototherapy methods in the complex sanatorium-resort treatment of patients with chronic obstructive pulmonary diseases. In: Materialyi XXX Mejdunarodnoy nauchno-prakticheskoy konferentsii. Primenenie lazerov v meditsine $\mathrm{i}$ biologii [Proceedings of the XXX International Scientific and Practical Conference. The use of lasers in medicine and biology]; 2008 Oct 8-11; Yalta. Kharkov: NPMBK Laser and Health Publ; 2008, p. 165-6. (in Russian)

34. Poteyko PI, Korobov AM, Korobov VA. The effectiveness of magnetic laser therapy in patients with pulmonary tuberculosis according to acupuncture diagnostics. In: Materialyi XXVII Mejdunarodnoy nauchno-prakticheskoy 
konferentsii. Primenenie lazerov v meditsine i biologii [Proceedings of the XXVII International Scientific and Practical Conference. The use of lasers in medicine and biology]; 2007 Apr 18-21; Kharkov. Kharkov: NPMBK Laser and Health Publ; 2007. p. 53-4. (in Russian)

35. Gradil GI, Kozko VN, Chorna TT, Merkulova NF, Mogilenets EI. Study of non-monochromatic infrared and visible radiation effectiveness in the complex treatment of community-acquired pneumonia in infectious disease hospital. In: Materialyi XXXVII Mejdunarodnoy nauchno-prakticheskoy konferentsii. Primenenie lazerov $\mathrm{v}$ meditsine i biologii [Proceedings of the XXXVII International Scientific Practical Conference. The use of lasers in medicine and biology]; 2012 Aug 24-29; Helsinki. Kharkov: VN Karazin KhNU Publ; 2012, p. 11. (in Russian)

36. Ashurov ShE, Baybekov IM. Morphological substantiation of the choice of types and methods of phototherapy in the complex treatment and prevention of perforation of gastroduodenal ulcers. In: Materialyi XXXXI Mejdunarodnoy nauchno-prakticheskoy konferentsii. Primenenie lazerov v meditsine i biologii [Proceedings of the XXXXI International Scientific Practical Conference. The use of lasers in medicine and biology]; 2014 May 28-31; Kharkov. Kharkov: VN Karazin KhNU Publ; 2014, p. 54-5. (in Russian)

37. Baybekov IM, Kabulov MK, Butaev AKh. The possibilities of using phototherapy in the treatment of the main complications of peptic ulcer disease (morphological aspects). In: Materialyi XXXXI Mejdunarodnoy nauchno-prakticheskoy konferentsii. Primenenie lazerov v meditsine i biologii [Proceedings of the XXXXI International Scientific and Practical Conference. The Use of Lasers in Medicine and Biology]; 2014 May 28-31; Kharkov. Kharkov: VN Karazin KhNU Publ, 2014, p. 55-6. (in Russian)

38. Scherbatska OO. Effectiveness of the Korobov photon matrix Korobov Barva-Flex/ JIK with corrective power systems. In: Materialyi XXVIII Mejdunarodnoy nauchno-prakticheskoy konferentsii. Primenenie lazerov v meditsine i biologii [Proceedings of the XXVIII International Scientific and Practical Conference. Use of Lasers in Medicine and Biology]; 2007 Oct 21-24; Yalta Kharkov: NPMBC Laser and Health Publ; 2007; p. 42-3. (in Russian)

39. Baklikov OL, Zabelin VG,. Chernyaev AL. Laser therapy of spinal osteochondrosis, accompanied by spondylolisthesis with severe pain syndrome. In: Materialyi XXV Mejdunarodnoy nauchno-prakticheskoy konferentsii. Primenenie lazerov v meditsine i biologii [Proceedings of the XXV International Scientific and Practical Conference. Application of lasers in medicine and biology]; 2006 May 24-28; Lutsk. Kharkiv: NPMBK Laser and Health Publ; 2006; p. 10. (in Russian)

40. Zhuravleva LV, Fedorov VA, Alexandrova NK. Application of phototherapy in patients with articular syndrome. In: Materialyi XXXVIII Mejdunarodnoy nauchno-prakticheskoy konferentsii. Primenenie lazerov v meditsine i biologii [Proceedings of the XXXVIII International Scientific and Practical Conference. The Use of Lasers in Medicine and Biology]; 2012 Oct 3-6; Yalta. Kharkov: VN Karazin KhNU Publ; 2012; p. 30-1. (in Russian)

41. Tondiy LD, Kas IV, Tondiy OL. The use of photon matrices Korobov "Barva-Flex" in the treatment of chronic pain syndrome in patients with vertebral osteochondrosis. In:
Materialyi XXI Mejdunarodnoy nauchno-prakticheskoy konferentsii. Primenenie lazerov v meditsine i biologii [Proceedings of the XXI International Scientific and Practical Conference. Application of lasers in medicine and biology]; 2004 May 26-29; Odessa. Kharkov: NPMBK Laser and Health Publ; 2004; p. 62-3. (in Russian)

42. Zhigarev YuA. Laser therapy of encephalitis of herpetic etiology. In: Materialyi XVII Mejdunarodnoy nauchno-prakticheskoy konferentsii. Primenenie lazerov v meditsine i biologii [Proceedings of the XVII International Scientific and Practical Conference. Application of lasers in medicine and biology]; 2002 May 21-23; Kharkov. Kharkov: NPMBK Laser and Health Publ; 2002; p. 32-3. (in Russian)

43. Zhigarev YuO. Prospects for low-intensity laser imaging in the complex neuroinfection. In: Materialyi XXV Mejdunarodnoy nauchno-prakticheskoy konferentsii. Primenenie lazerov v meditsine i biologii [Proceedings of the XXV International Scientific and Practical Conference. Application of lasers in medicine and biology]; 2006 May 24-28; Lutsk. Kharkov: NPMBK Laser and Health Publ; 2006; p. 28-30. (in Russian)

44. Muliar OS. Prevention of acute respiratory viral infection in the minds of the child sanatorium using light. In: Materialyi yubileynoy XX Mejdunarodnoy nauchno-prakticheskoy konferentsii. Primenenie lazerov v meditsine i biologii [Proceedings of the jubilee XX International Scientific and Practical Conference. Application of lasers in medicine and biology]; 2003 Oct 8-11; Yalta. Kharkov: NPMBC Laser and Health Publ; 2003; p. 53. (in Ukrainian)

45. Kovbasyuk DV, Chepela NV, Danilchuk AO, Prisyazhnyuk NV. Experience of using photon matrices in the complex treatment of vascular diseases of the brain. In: Materials XLIX International Scientific and Practical Conference. Application of lasers in medicine and biology and 2nd Gamaleia's Readings; 2018 Oct 3-7; Hajduszoboszlo. Kharkov: Petrov Publ; 2018; p. 122-4. (in Ukrainian)

46. Filipovska DI, Neduraieva IV, Kosman VA, Shevchenko NI. Experience of light treatment of cerebral circulatory disorders in the conditions of the territorial social service center. In: Materialyi XLVIII Mejdunarodnoy nauchno-prakticheskoy konferentsii. Zastosuvannya lazeriv $\mathrm{v}$ meditsine i biologii [Materials XLVIII International Scientific and Practical Conference. Application of lasers in medicine and biology]; 2018 May 24-25; Kharkiv. Kharkiv: Petrov Publ; 2018; p. 98-100. (in Ukrainian)

47. Zakutiy MM, Marchuk TA, Filipovska DI. Improving the technology of light therapy of the cerebral blood circulation disorders in the conditions of the territorial social service center. In: Materials XLIX International Scientific and Practical Conference. Application of lasers in medicine and biology and 2nd Gamaleia's Readings; 2018 Oct 3-7; Hajduszoboszlo. Kharkiv: Petrov Publ; 2018, p. 24-6. (in Ukrainian)

48. Posokhov NF, Korobov AM, Makarov VN, Vorobyev VV, Kostyukovskaya AE,. Nazarchuk AG, et al. Successful treatment of dyscirculatory encephalopathy using the Korobov-Posokhov photon matrix Barva-CNS/PH (case study). In: Materiali XLII Mijnarodnoi naukovo-praktichnoi konferentsii. Zastosuvannya lazeriv u meditsini ta biologii [Materials XLII International Scientific and Practical Conference. Application of lasers in medicine and biology]; 2014 Des 11-13; Yaremche. Kharkiv: Petrov Publ; 2014; p. 43-5. (in Russian) 